\title{
Levorphanol Tartrate
}

National Cancer Institute

\section{Source}

National Cancer Institute. Levorphanol Tartrate. NCI Thesaurus. Code C47586.

The tartrate salt form of levorphanol, a synthetic phenanthrene with potent opioid analgesic activity. Levorphanol tartrate mimics the actions of endogenous peptides at CNS opioid receptors, thereby producing the characteristic morphine-like effects on the mu-opioid receptor, including analgesia, euphoria, sedation, respiratory depression, miosis, bradycardia and physical dependence. 